\title{
A Study on Changes in Women's Makeup Interest and Use Patterns Before and After the Outbreak of COVID-19
}

\author{
Yun-Mi Park ${ }^{1 *}$, Hwi-Yool Kim ${ }^{2}$ \\ ${ }^{1}$ Department of Veterinary Medicine, Konkuk University, Seoul, Korea \\ ${ }^{2}$ Department of Humanimage, Konkuk University, Seoul, Korea
}

\author{
*Corresponding author: Yun-Mi Park, \\ Department of Humanimage, Konkuk \\ University, 120 Neungdong-ro, Gwangjin-gu, \\ Seoul 05029, Korea. \\ Tel.: +82 24504036 \\ Fax: +8224463747 \\ Email: 5002600@hanmail.net
}

Received February 11, 2021

Revised March 11, 2021

Accepted March 11, 2021

Published March 30, 2021

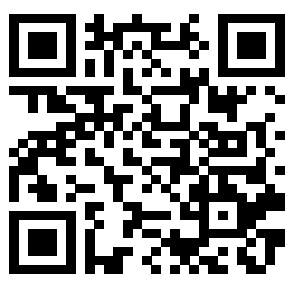

\begin{abstract}
Purpose: The purpose of this study is to investigate through empirical analysis how the outbreak of Corona 19 has changed women's interest in and use of makeup in domestic women in their teens to 40s. Methods: A survey was conducted on women in their teens to 40s residing in Seoul from the third week to the fourth week of September 2020, and statistical processing of the collected data was analyzed using the SPSS 26.0 program. Results: The overall interest in makeup was found to have been lower after the outbreak of Corona 19. This means that the overall interest in make-up, the need for make-up, product purchase, and appearance satisfaction have decreased after the outbreak of Corona 19 compared to before the outbreak of Corona 19. In addition, lip-oriented makeup such as lip makeup and lipstick appeared to have decreased compared to before the outbreak of Corona 19, which was found to affect women's use of cosmetics. Conclusion: It has been shown that the mandatory use of masks reduces the purchase of cosmetics and also reduces makeup for beauty purposes by women. In addition, it was found that instead of minimizing makeup on the part (lips) that is not exposed when wearing a mask, makeup on the part (eyes or face) exposed when wearing a mask is rather more interested.
\end{abstract}

Keywords: Appearance interest, Corona 19, Cosmetic interest, Cosmetic use, Makeup

\section{Introduction}

화장은 인간의 근본적 욕구인 미적 욕구를 충족시켜줌과 동시에 자기 자신을 재발견하여 변화된 새로운 모습으로 바꾸어주어 자신의 모습을 더욱 세련되고 매력적인 이미지, 개성적인 이미지로 나타낼 수 있는 자기표현의 수단이다(Guo \& Sim, 2009; Lee \& O, 2010). 화장은 외모를 가꾸고 보완하며, 가시적인 효과를 상승시킬 수 있으 므로 사회생활을 원활하고 효과적으로 수행하기 위한 하나의 도구이 지만 코로나 19 로 인해 사회문화와 일상이 변함에 따라 여성들의 화 장에 대한 관심도나 트랜드 역시 변할 것으로 예상된다.

코로나 19 로 인해 여성들의 외출 감소와 비대면 소비문화 확산 및 마스크 착용 의무화에 따라 화장에 대한 기대·소비 심리가 위축되었 고 이로 인해 화장 제품에 대한 수요가 필연적으로 낮아지면서 여성 들의 화장 관심도와 사용실태가 변하고 있다. 비대면 형식의 사회 교
류가 증가함에 따라 화장에 대한 관심이 줄어들었고 마스크 착용 일 상화로 눈 중심의 화장 트랜드가 생기게 된 것인데, 사람과 사람간의 언택트(Untact)가 장려되고 사회적 거리두기가 권장됨에 따라 코로 나 19 는 여성들의 화장 관심도나 사용 실태에 변화가 생기고 있는 것 이다.

화장 관심도는 현재 유행하고 있는 가장 본인다운 꾸밈없는 생 얼 굴을 화장으로 연출하여 자존감을 높여 자신을 표출하는 정도를 의 미하는 것이며, 외모관리 방법의 화장은 본인의 개성을 표현하고 자 신의 변모된 이미지를 표출하기에 필요한 행위로, 획일화된 유행에 서 탈피하여 자신만의 이미지를 만드는데 중요한 행위라 할 수 있다 (Graham \& Jougar, 1981; Guo \& Sim, 2009; De Cuyper, 2008; Korichi et al., 2008) 하지만 코로나19 발생 이후에 마스크 착용과 함께 일상이 이어지면서 피부 고민이 달라지면서 스킨케어에 대한 관심은 높아진 반면에 메이크업에 대한 전반적인 관심도는 줄어드는 
등 화장 관심도가 변화하고 있다.

또한 코로나 19 는 여성들의 화장 사용 실태에도 영향을 주고 있 는데 닐슨 코리아의 조사 결과에 따르면, 파운데이션(13\%), 컨실러 (12\%), 프라이머(11\%) 등 베이스 메이크업 제품과 립스틱(17\%), 립 틴트 $(9 \%)$ 등 색조 화장품 매출은 모두 감소세로 나타났다. 또한 $\mathrm{G}$ 마 켓의 화장품 매출 분석 결과, 파운데이션·파우더 등 베이스 메이크 업 제품의 매출은 전년 동기 대비 $22 \%$, 립과 블러셔 제품은 $15 \%$ 가 감소하여 그 추세가 계속 이어질 것으로 예상이 가능하다.

이렇듯 코로나 19 는 여성들의 화장에 대한 관심도나 사용 트렌드 를 변화시키고 있으며, 뷰티산업에서는 이러한 여성들의 화장 트렌 드 변화를 인식하고 이를 극복하기 위한 마케팅 및 제품개발에 새로 운 대응 전략을 수립이 필요한 시점이라고 할 수 있다. 하지만 그럼 에도 불구하고 코로나 19 가 여성들의 화장관심도나 사용실태에 미친
영향을 살펴본 연구는 양적으로 매우 미흡한 실정이다. 그나마 $\mathrm{Kim}$ $\& \mathrm{Li}$ (2020)가 코로나19로 인한 마스크 착용과 메이크업 만족도간의 관계를 살펴보면서 코로나19 전후 메이크업 정도 차이는 코로나 19 이후 메이크업 정도가 이전보다 낮으며, 마스크 착용 이후 메이크업 정도가 줄었음을 확인하였지만 사용실태 변화를 살펴보는 데에는 한 계가 있었다.

따라서 이러한 시점에 코로나 19 시대에 여성들의 화장에 대한 관 심도와 화장품 사용실태를 실증분석을 통해 살펴보는 것은 뷰티산업 의 대응전략 수립이 필요한 시점에서 매우 의미가 있을 것이다. 이에 본 연구에서는 국내 10대-40대 여성들을 대상으로 코로나19 발생 이 여성들의 화장에 대한 관심도와 사용에 어떠한 변화를 주었는지 를 실증분석을 통해 규명해 보고자 한다.

Table 1. Characteristics of survey subjectst

\begin{tabular}{|c|c|c|c|}
\hline & Item & $\mathrm{N}$ & $\%$ \\
\hline \multirow{4}{*}{ Age } & Teens & 78 & 28.8 \\
\hline & $20 s$ & 58 & 21.4 \\
\hline & $30 \mathrm{~s}$ & 62 & 22.9 \\
\hline & $40 s$ & 73 & 26.9 \\
\hline \multirow{2}{*}{ Marital Status } & Single & 164 & 60.5 \\
\hline & Married & 107 & 39.5 \\
\hline \multirow{3}{*}{ Final education } & High school & 138 & 50.9 \\
\hline & College/University & 107 & 39.5 \\
\hline & Graduate school or higher & 26 & 9.6 \\
\hline \multirow{5}{*}{ Job } & Student & 112 & 41.3 \\
\hline & Housewife & 44 & 16.2 \\
\hline & Employee & 57 & 21.0 \\
\hline & Owner-Operator & 24 & 8.9 \\
\hline & Etc & 34 & 12.5 \\
\hline \multirow{5}{*}{ Average monthly income } & Less than 500,000 won & 127 & 46.9 \\
\hline & 500,000 to 1 million won & 14 & 5.2 \\
\hline & 1 to 3 million won & 81 & 29.9 \\
\hline & 3 to 5 million won & 26 & 9.6 \\
\hline & 5 million won or more & 23 & 8.5 \\
\hline \multirow{4}{*}{ Frequency of going out } & Less than once a week & 54 & 19.9 \\
\hline & About 3 times a week & 73 & 26.9 \\
\hline & Everyday & 132 & 48.7 \\
\hline & Etc & 12 & 4.4 \\
\hline \multirow{6}{*}{ Average time to go out } & $1-3 \mathrm{~h}$ & 55 & 20.3 \\
\hline & $4-6 \mathrm{~h}$ & 94 & 34.7 \\
\hline & $7-9 \mathrm{~h}$ & 70 & 25.8 \\
\hline & $10-12 \mathrm{~h}$ & 36 & 13.3 \\
\hline & $12 \mathrm{~h}$ or more & 16 & 5.9 \\
\hline & Total & 271 & 100.0 \\
\hline
\end{tabular}




\section{Methods}

\section{1. 연구대상 및 자료 수집방법}

본 조사에서는 서울시에 거주하는 10 대-40대 여성들을 조사대상 으로 하였다. 이들 여성들을 표본 집단으로 하여 2020년 9월 셋째 주부터 넷째 주까지 2 주 동안 실시하였다. 설문조사는 고등학교, 대 학교, 미용실, 뷰티샵, 아파트단지 등 순회하여 응답에 협조한 조사 대상 여성들에게 본 연구의 취지와 목적에 대해 충분히 설명하고, 동 의를 얻은 후 자기기입법에 의해서 설문지를 작성하도록 하였다. 회 신된 설문지 300 부 가운데 불성실한 응답을 제외하고 유효한 자료 인 271명만 최종 분석에 활용하였다(Table 1). 본 연구는 선행논문 (Choi \& Heo, 2019; Na \& Song, 2014; Tae, 2016; Kim \& Kwon, 2014; Ryu \& Kim, 2020)의 선행연구에서 사용된 설문지를 참고하 고 연구목적에 타당하도록 보완하고 수정하여 구성된 설문지를 이용 하였다.

\section{2. 연구도구}

본 연구에서 사용된 화장 관심도 측정도구의 경우 Choi \& $\mathrm{HeO}$ (2019)의 연구에서 타당도와 신뢰도가 검증된 측정도구를 사용하였 다. 화장 관심도는 청소년들이 화장하는 것에 대한 인식, 외모에 대 한 관심, 화장에 대한 동기, 자신의 외모, 신체, 피부 상태 및 화장 후 의 만족도, 타인들보다 화장에 대한 유행의 선도 여부, 화장제품을 구입의 즐거움, 화장을 할 때, 주변사람의 의견 참고 및 실제 구매에 반영 여부, 화장에 대한 지출 정도, 화장을 통한 스트레스 해소 여부, 화장에 대한 필요성 증가 정도로 측정하였으며, 단일 요인, 총 22 문 항으로 구성하였다. 모든 문항은 Likert 5 점 척도로 측정하였다.

\section{3. 분석방법}

본 연구를 위해서 수집된 자료의 통계 처리는 SPSS 26.0 프로그램
을 이용하여 분석하였다. 첫째, 조사대상 서울시 거주 10 대-40대 여 성들의 인구통계학적 특성을 알아보기 위하여 빈도분석(frequency analysis)을 실시하였다. 둘째, 본 연구에서 분석하고자 하는 개념을 알맞게 측정하였는가를 알아보기 위한 변수들을 측정하기 위해 측정 도구(설문지)의 신뢰성과 타당성을 검증하고 탐색적 요인분석(EFA) 을 실시하며 Cronbach's $\alpha$ 계수를 산출하고자 한다. 요인분석에 의 한 요인 적재치(factor loading)는 0.5 이상 기준으로 맞추고, 고유치 (eigen value)는 1.0 이상을 기준으로 한다. 셋째, 코로나19 발생 이 전·이후의 따른 화장에 대한 관심도 차이를 검증하기 위하여 독립 $t-$ 검정을 실시하였다. 넷째, 코로나 19 발생 이전·이후의 따른 화장품 사용실태 차이를 검증하기 위하여 다중응답분석에 의한 교차분석을 실시하였다. 이상의 모든 분석은 통계적 유의수준 0.05 수준으로 검 증하였다.

\section{Results and Discussion}

\section{1. 코로나19에 의한 화장관심도 변화}

본 연구에 사용된 측정도구의 개념타당성 검증을 위해 탐색적 요 인분석과 주성분 분석을 실시하였다, 요인회전은 베리맥스(Varimax) 방식을 사용하였으며, 요인적재량이 0.4 이하인 문항인 1 번, 2 번, 14 번, 18 번 4 개 문항 등 타당성이 결여된 항목은 제거하여 개념 타 당성을 확보하였다. 또한 요인분석을 통해 추출된 연구변인들을 구 성하고 있는 항목들의 내적 일관성을 나타내는 신뢰도 검증을 위해 Cronbach's 계수를 산출하였다.

요인분석 결과 표본 적합도를 검증하는 $\mathrm{KMO}$ 값이 0.791로 나타 났으며, 요인분석의 타당성을 나타내는 Bartlett의 구형성 검증 결과 $\mathrm{x}^{2}=1968.676(\mathrm{df}=153, p<0.001)$ 로 유의하여 수집된 데이터와 측정 항목은 요인분석을 수행하기에 적합한 것으로 나타나 5 개 요인이 도

Table 2. Changes in Makeup interest

\begin{tabular}{|c|c|c|c|c|c|c|}
\hline Item & Time & $\mathrm{N}$ & $\mathrm{M}^{1)}$ & $\mathrm{SD}^{2)}$ & $t$ & $p$ \\
\hline \multirow{2}{*}{$\begin{array}{l}\text { Psychological } \\
\text { satisfaction }\end{array}$} & Before & 271 & 3.37 & 0.81 & \multirow{2}{*}{1.915} & \multirow{2}{*}{0.056} \\
\hline & After & 271 & 3.24 & 0.83 & & \\
\hline \multirow{2}{*}{ Trend } & Before & 271 & 2.31 & 0.85 & \multirow{2}{*}{1.415} & \multirow{2}{*}{0.158} \\
\hline & After & 271 & 2.21 & 0.81 & & \\
\hline \multirow{2}{*}{$\begin{array}{l}\text { Need for } \\
\text { makeup }\end{array}$} & Before & 271 & 3.50 & 0.68 & \multirow{2}{*}{$5.019^{* * *}$} & \multirow{2}{*}{0.000} \\
\hline & After & 271 & 3.19 & 0.75 & & \\
\hline \multirow{2}{*}{$\begin{array}{l}\text { Need for } \\
\text { makeup }\end{array}$} & Before & 271 & 2.86 & 0.83 & \multirow{2}{*}{$2.163^{*}$} & \multirow{2}{*}{0.031} \\
\hline & After & 271 & 2.70 & 0.84 & & \\
\hline \multirow{2}{*}{$\begin{array}{l}\text { Appearance } \\
\text { satisfaction }\end{array}$} & Before & 271 & 3.08 & 0.85 & \multirow{2}{*}{$5.097^{* * *}$} & \multirow{2}{*}{0.000} \\
\hline & After & 271 & 2.71 & 0.87 & & \\
\hline \multirow{2}{*}{ Total } & Before & 271 & 2.99 & 0.53 & \multirow{2}{*}{$4.175^{* * *}$} & \multirow{2}{*}{0.000} \\
\hline & After & 271 & 2.79 & 0.56 & & \\
\hline
\end{tabular}

${ }^{*} p<0.05 ;{ }^{* * *} p<0.001,{ }^{1)} \mathrm{M}$, mean, ${ }^{2)} \mathrm{SD}$, standard deviation. 
출되었으며, 모든 항목의 요인 적재량이 0.5 이상으로 타당성이 확보 되었다. 또한 신뢰도 분석 결과 심리적 만족 Cronbach's $\alpha=0.819$, 유 행 Cronbach's $\alpha=0.863$, 화장 필요성 Cronbach's $\alpha=0.616$, 제품 구 매 Cronbach's $\alpha=0.621$, 외모 만족 Cronbach's $\alpha=0.610$ 으로 모두 기 준값이 0.6 보다 높게 나타나 측정 자료의 내적일관성이 확보되었다.

코로나 19 발생 이전·이후의 따른 화장에 대한 관심도 차이를 검 증한 결과는 Table 2 와 같다. 화장에 대한 관심도 전체와 하위 영역 인 화장 필요성, 제품 구매, 외모 만족에서 유의한 차이가 있었다. 화 장 필요성은 코로나19 발생 이후 $(\mathrm{M}=3.19)$ 가 이전 $(\mathrm{M}=3.50)$ 보다 더 낮았으며, 유의한 차이가 있었다 $p<0.001)$. 제품 구매는 코로나 19
발생 이후 $(\mathrm{M}=2.70)$ 가 이전 $(\mathrm{M}=2.86)$ 보다 더 낮았으며, 유의한 차이 가 있었다 $(p<0.05)$. 외모 만족은 코로나19 발생 이후 $(\mathrm{M}=2.71)$ 가 이 전(M=3.08)보다 더 낮았으며, 유의한 차이가 있었다 $(p<0.001)$. 화 장에 대한 전반적인 관심도는 코로나 19 발생 이후 $(\mathrm{M}=2.79)$ 가 이전 $(\mathrm{M}=2.99)$ 보다 더 낮았으며, 유의한 차이가 있었다 $(p<0.001)$, 결론 적으로 코로나19 발생 이전에 비해 이후에는 화장에 대한 전반적인 관심도와 화장 필요성, 제품 구매, 외모 만족 등이 유의하게 낮아진 것으로 나타났다.

연령대에 따른 코로나19 발생 이전·이후의 화장 관심도 차이를 검증한 결과는 Table 3 과 같다. 분석결과 모든 연령층에서 화장관심

Table 3. Changes in makeup interest by age

\begin{tabular}{|c|c|c|c|c|c|c|}
\hline Item & Time & $\mathrm{N}$ & $\mathrm{M}^{1)}$ & $\mathrm{SD}^{2)}$ & $t$ & $p$ \\
\hline \multirow{2}{*}{ Teens } & Before & 78 & 3.09 & 0.54 & \multirow{2}{*}{1.891} & \multirow{2}{*}{0.061} \\
\hline & After & 78 & 2.92 & 0.58 & & \\
\hline \multirow{2}{*}{$20 \mathrm{~s}$} & Before & 58 & 3.11 & 0.48 & \multirow{2}{*}{1.206} & \multirow{2}{*}{0.230} \\
\hline & After & 58 & 3.00 & 0.47 & & \\
\hline \multirow{2}{*}{$30 \mathrm{~s}$} & Before & 62 & 2.96 & 0.51 & \multirow{2}{*}{$3.257^{* *}$} & \multirow{2}{*}{0.001} \\
\hline & After & 62 & 2.65 & 0.55 & & \\
\hline \multirow{2}{*}{$40 \mathrm{~s}$} & Before & 73 & 2.81 & 0.51 & \multirow{2}{*}{$2.254^{*}$} & \multirow{2}{*}{0.026} \\
\hline & After & 73 & 2.62 & 0.51 & & \\
\hline \multirow{2}{*}{ Total } & Before & 271 & 2.99 & 0.55 & \multirow{2}{*}{$3.225^{* * *}$} & \multirow{2}{*}{0.000} \\
\hline & After & 271 & 2.80 & 0.59 & & \\
\hline
\end{tabular}

${ }^{*} p<0.05 ;{ }^{* *} p<0.01 ;{ }^{* * *} p<0.001 ;{ }^{1)} \mathrm{M}$, mean; ${ }^{2)} \mathrm{SD}$, standard deviation.

Table 4. Changes in Makeup interest by frequency of outing and time out

\begin{tabular}{|c|c|c|c|c|c|c|c|}
\hline & Item & Time & $\mathrm{N}$ & $\mathrm{M}^{1)}$ & $\mathrm{SD}^{2)}$ & $t$ & $p$ \\
\hline \multirow{8}{*}{$\begin{array}{l}\text { Frequency of } \\
\text { outing }\end{array}$} & \multirow{2}{*}{$\begin{array}{l}\text { Less than once a } \\
\text { week }\end{array}$} & Before & 54 & 2.83 & 0.61 & \multirow{2}{*}{0.855} & \multirow{2}{*}{0.394} \\
\hline & & After & 54 & 2.72 & 0.66 & & \\
\hline & \multirow{2}{*}{3 times a week } & Before & 73 & 3.07 & 0.42 & \multirow{2}{*}{$3.350^{* *}$} & \multirow{2}{*}{0.001} \\
\hline & & After & 73 & 2.82 & 0.49 & & \\
\hline & \multirow{2}{*}{ Everyday } & Before & 132 & 3.00 & 0.54 & \multirow{2}{*}{$3.179^{* *}$} & \multirow{2}{*}{0.002} \\
\hline & & After & 132 & 2.79 & 0.55 & & \\
\hline & \multirow{2}{*}{ Total } & Before & 271 & 2.97 & 0.51 & \multirow{2}{*}{$3.122^{* * *}$} & \multirow{2}{*}{0.000} \\
\hline & & After & 271 & 2.78 & 0.52 & & \\
\hline \multirow{10}{*}{ Time out } & \multirow{2}{*}{$1-3$ hours } & Before & 55 & 2.92 & 0.50 & \multirow{2}{*}{$2.207^{*}$} & \multirow{2}{*}{0.029} \\
\hline & & After & 55 & 2.71 & 0.48 & & \\
\hline & \multirow{2}{*}{ 4-6 hours } & Before & 94 & 2.97 & 0.54 & \multirow{2}{*}{$3.115^{* *}$} & \multirow{2}{*}{0.002} \\
\hline & & After & 94 & 2.72 & 0.58 & & \\
\hline & \multirow{2}{*}{$7-9$ hours } & Before & 70 & 3.06 & 0.48 & \multirow{2}{*}{1.324} & \multirow{2}{*}{0.188} \\
\hline & & After & 70 & 2.95 & 0.51 & & \\
\hline & \multirow{2}{*}{$\begin{array}{l}10 \text { hours or } \\
\text { more }\end{array}$} & Before & 52 & 2.99 & 0.58 & \multirow{2}{*}{1.556} & \multirow{2}{*}{0.123} \\
\hline & & After & 52 & 2.81 & 0.61 & & \\
\hline & \multirow{2}{*}{ Total } & Before & 271 & 3.00 & 0.50 & \multirow{2}{*}{$2.336^{* * *}$} & \multirow{2}{*}{0.000} \\
\hline & & After & 271 & 2.80 & 0.53 & & \\
\hline
\end{tabular}

${ }^{*} p<0.05 ;{ }^{* *} p<0.01 ;{ }^{* * *} p<0.001 ;{ }^{1)} \mathrm{M}$, mean, ${ }^{2} \mathrm{SD}$, standard deviation. 
도는 낮아지는 경향을 확인할 수 있었으며, 특히 30대와 40대의 경 우에는 화장관심도가 코로나 19 발생 전과 후에 있어 통계적으로 유 의한 차이가 있는 것으로 나타났다( $p<0.01)$.

이러한 결과는 10 대나 20 대와 같은 젊은 층의 여성들은 사회활동 보다는 자신의 아름다움을 표현하고(Lee \& O, 2010), 자기만족을 하는 경향이 높기 때문에(Na \& Song, 2014) 코로나19에 의한 화장 관심도의 차이가 없는 것으로 판단된다. 반면에 대외활동이나 사회 활동을 활발하게 하는(Kim \& Kim, 2020) 시기인 30-40대의 여성 들은 코로나 19 로 인해 재택근무나 비대면 사회활동 증가에 따라 코 로나19 이전에 비해 화장에 대한 관심도가 낮아진 것으로 판단된다. 이러한 결과는 10-20대 여성과 30-40대 여성들의 화장 목적이 서 로 상이하다는 것을 시사하는 것이다.

외출 빈도와 시간에 따른 화장관심도의 차이를 살펴본 결과 는 Table 4 와 같다. 먼저 외출 빈도에 따른 화장관심도 차이를 보 면, 외출 빈도가 높을수록 화장에 대한 관심도가 코로나19 발생 전 $(\mathrm{M}=2.97)$ 보다 코로나19 발생 후 $(\mathrm{M}=2.78)$ 에 통계적으로 유의하게 낮아지는 것으로 나타났다 $(p<0.01)$. 또한 외출시간에 따른 화장관심 도 차이에도 외출시간이 길수록 화장에 대한 관심도가 코로나19 발 생 전 $(\mathrm{M}=3.00)$ 보다 코로나19 발생 후 $(\mathrm{M}=2.80)$ 에 통계적으로 유의 하게 낮아지는 것으로 나타났다 $(p<0.01)$. 이러한 결과는 외출을 자 주하고 외출시간이 긴 여성의 경우 화장에 대한 관심도가 코로나19 발생 전에 비해 발생 후에 낮아진 것을 의미하는 것으로 외출 시 마 스크 착용이 의무화됨에 따른 결과로 판단된다. 즉 마스크를 착용하 게 되면 얼굴 노출 부위가 적어짐에 따라 화장 부위는 물론이고 화장 의 보다 세밀하게 할 필요가 없어지게 됨에 따라 여성들의 화장관심
도를 낮춘 것으로 판단된다.

\section{2. 코로나 19 에 의한 화장 사용실태 변화}

코로나19 발생 이전·이후별 가장 많이 사용하는 제품으로는 Table 5 와 같이 코로나19 발생 이전에는 파운데이션(17.6\%), 파우더 (10.8\%), B.B크림(9.9\%) 순으로 많았고, 코로나19 발생 이후에는 파 운데이션(16.9\%), B.B크림(12.5\%), 파우더(12.2\%) 순으로 많았다. 특히 코로나19 전후의 화장품 사용량 차이를 살펴보면, 코로나 19 이 후에 마스카라, 아이브로우, B.B크림 순으로 화장품 사용량이 증가 한 것을 알 수 있는데 이는 여성들의 화장실태가 파운데이션이나 파 우더 등을 통한 얼굴전체 화장중심에서 마스카라, 아이브로우 등의 눈화장 중심으로 변화한 것으로 볼 수 있다. 이러한 변화는 코로나 19 예방을 위한 마스크 착용에 기인한 것으로 노출이 안 되는 부위 까지 화장을 하던 기존 방식에서 마스크 착용에도 노출되는 부위인 눈 중심의 화장으로 화장 트랜드가 변하고 있음을 시사하는 것이다. 여성들이 차도르를 착용하는 중동 문화권의 경우 드러나는 곳이 눈 밖에 없기 때문에 강렬한 눈 화장을 하는 것과 일맥상통한다고 할 수 있다. 또한 마스크 착용으로 노출이 되지 않는 입술이나 볼(뺨)의 경 우에는 마스크를 착용한 코로나19 발생이후에 그 사용량이 대폭 줄 어든 것으로 나타남에 따라 여성들이 사용하는 화장품에 코로나 19 가 영향을 미치고 있음을 알 수 있다.

또한 여성들의 화장품 사용 목적과 부위를 살펴본 결과(Table 6), 코로나19 발생 이전에는 화장 목적이 자기만족(29.2\%), 결점커버 (29.2\%), 대인관계 예의(21.4\%)의 순으로 나타났지만 코로나19 발 생 이후에는 이러한 목적으로 화장을 하는 여성들이 감소하고 피부

Table 5. Makeup products

\begin{tabular}{lrrr}
\hline \multirow{2}{*}{ Item } & \multicolumn{2}{c}{ Time } & Variation (\%) \\
\cline { 2 - 3 } Mascara & Before & After & 23 \\
Eyebrow & $38(4.8)$ & $47(6.9)$ & $75(11.0)$ \\
B.B cream & $65(8.2)$ & $85(12.5)$ & 15 \\
powder & $78(9.9)$ & $83(12.2)$ & -2 \\
Eyeliner & $85(10.8)$ & $47(6.9)$ & -6 \\
Makeup base & $50(6.3)$ & $61(8.9)$ & -14 \\
foundation & $71(9.0)$ & $115(16.9)$ & -17 \\
Eye shadow & $139(17.6)$ & $48(7.0)$ & -21 \\
Lip gloss & $61(7.7)$ & $25(3.7)$ & -24 \\
Ball Touch & $33(4.2)$ & $21(3.1)$ & -30 \\
Twin cake & $30(3.8)$ & $14(2.1)$ & -33 \\
Tint (lip product) & $21(2.7)$ & $45(6.6)$ & -38 \\
False eyelashes & $73(9.2)$ & $5(0.7)$ & -44 \\
Lipstick & $9(1.1)$ & $11(1.6)$ & -70 \\
\hline
\end{tabular}

"Multiple response results. 
보호를 위해 화장하는 여성들의 비중이 $137 \%$ 증가한 것을 알 수 있 었으며, 여성들의 화장목적이 코로나19 전후로 유의한 차이가 있는 것으로 나타났다 $(p<0.001)$. 이러한 결과는 여성들의 화장목적이 여 성미 추구에서 이제는 마스크 착용으로 인해 발생되는 피부 트러블 을 완화하기 위한 목적으로 화장목적이 변화된 것으로 판단된다. 이 는 Kim \& Li (2020)가 주장한 여성들이 마스크 착용으로 인해 피부 트러블이 증가한다는 연구 결과와 맥락을 같이한다. 또한 화장부위 를 보면, Eyebrow는 코로나19 전에 비해 $91 \%$ 증가한 반면에 입술화 장(lip)은 $82 \%$ 감소한 것으로 나타났는데 이러한 변화는 마스크 착용 으로 입술화장의 필요성이 줄어든 대신 상대적으로 눈화장의 관심도 가 증가한 것으로 판단된다.

한편 Table 7과 같이 여성들의 코로나19 발생 전후로 화장품 구매 방법과 구매비용에 있어 통계적으로 유의한 차이가 있는 것으로 각 각 나타났다 $(p<0.001, p<0.001)$. 먼저 화장품 구매방법을 살펴본 결 과, 코로나19 발생 이전에는 화장품 전문점이 가장 많았고(42.8\%), 코로나19 발생 이후에는 통신판매(홈쇼핑 또는 인터넷)가 가장 많았

Table 6. Makeup purpose and parts

\begin{tabular}{|c|c|c|c|c|c|}
\hline & \multirow{2}{*}{ Item } & \multicolumn{2}{|c|}{ Time } & \multirow{2}{*}{ Variation (\%) } & \multirow{2}{*}{$\mathrm{X}^{2} / p$} \\
\hline & & Before & After & & \\
\hline \multirow{7}{*}{ Makeup purpose } & Skin protection & $19(7.0)$ & 45 (16.6) & 137 & \multirow{7}{*}{$25.374 / 0.000^{* * *}$} \\
\hline & Interpersonal courtesy & $58(21.4)$ & $50(18.5)$ & -14 & \\
\hline & To look beautiful & $30(11.1)$ & $22(8.1)$ & -27 & \\
\hline & Flaw cover & $79(29.2)$ & $65(24.0)$ & -18 & \\
\hline & Self-satisfaction & $81(29.9)$ & $69(25.5)$ & -15 & \\
\hline & Etc & $4(1.5)$ & $20(7.4)$ & 400 & \\
\hline & Total & $271(100.0)$ & $271(100.0)$ & - & \\
\hline \multirow{8}{*}{ Makeup parts } & Skin & $90(33.2)$ & $72(26.6)$ & -20 & \multirow{8}{*}{$50.22 / .000^{* * *}$} \\
\hline & Eyebrow & $44(16.2)$ & $84(31.0)$ & 91 & \\
\hline & Eye makeup & $94(34.7)$ & $89(32.8)$ & -5 & \\
\hline & Blusher & $1(0.4)$ & $0(0.0)$ & -100 & \\
\hline & Lips & $38(14.0)$ & $7(2.6)$ & -82 & \\
\hline & Face (Cheek) & $3(1.1)$ & $3(1.1)$ & 0 & \\
\hline & Etc & $1(0.4)$ & $16(5.9)$ & 1,500 & \\
\hline & Total & 271 (100.0) & 271 (100.0) & - & \\
\hline
\end{tabular}

${ }^{* * *} p<0.001$.

Table 7. Cosmetics purchase method and purchase cost

N (\%)

\begin{tabular}{|c|c|c|c|c|c|}
\hline & \multirow{2}{*}{ Item } & \multicolumn{2}{|c|}{ Time } & \multirow{2}{*}{ Variation (\%) } & \multirow{2}{*}{$\mathrm{X}^{2} / p$} \\
\hline & & Before & After & & \\
\hline \multirow{7}{*}{ Purchase method } & Door-to-door sales & $56(20.7)$ & $27(10.0)$ & -52 & \multirow{7}{*}{$58.781 / 0.000^{* * *}$} \\
\hline & Home shopping, Internet & $58(21.4)$ & $135(49.8)$ & 133 & \\
\hline & Department store & $34(12.5)$ & $24(8.9)$ & -30 & \\
\hline & Cosmetics store & $116(42.8)$ & $69(25.5)$ & -41 & \\
\hline & Hospital, pharmacy & $2(0.7)$ & $2(0.7)$ & 0 & \\
\hline & Etc & $5(1.8)$ & $14(5.2)$ & 180 & \\
\hline & Total & $271(100.0)$ & $271(100.0)$ & - & \\
\hline \multirow{6}{*}{ Purchase cost } & $10,000-30,000$ won & $83(30.6)$ & $134(49.4)$ & 61 & \multirow{6}{*}{$32.508 / 0.000^{* * \star}$} \\
\hline & $30,000-50,000$ won & $67(24.7)$ & $66(24.4)$ & -2 & \\
\hline & $50,000-70,000$ won & $53(19.6)$ & $46(17.0)$ & -13 & \\
\hline & $70,000-100,000$ won & $44(16.2)$ & $15(5.5)$ & -66 & \\
\hline & 100,000 won or more & $24(8.9)$ & $10(3.7)$ & -58 & \\
\hline & Total & $271(100.0)$ & $271(100.0)$ & - & \\
\hline
\end{tabular}

${ }^{* * *} p<0.001$. 
으며(49.8\%). 코로나19 발생 이전에는 색조화장품을 주로 화장품 전 문점에서 색조발색 시연 등으로 인해 구매하는 여성들이 많았지만 코로나19 발생 이후에는 비대면과 사회적 거리두기로 비대면 구매 방식인 통신판매(홈쇼핑 또는 인터넷)를 선호하는 것으로 나타났다.

또한 화장품 구매비용을 보면, 코로나 19 발생과 관계없이 화장품 구매비용은 1 만원 -3 만원 비용의 화장품을 선호하는 것으로 나타났 다. 특히 3 만원 미만의 화장품은 코로나 19 이후에 $61 \%$ 증가한 것으 로 나타난 반면에 3 만원 이상의 화장품 구매는 코로나 19 발생 이후 감소한 것으로 나타났다. 특히 7만원-10만원 화장품은 코로나 19 이 전(16.2\%)에 비해 이후 $(5.5 \%)$ 에 크게 감소하였는데 이는 여성들의 인식하는 화장에 대한 중요성이나 필요성이 코로나19 영향으로 감 소하였기 때문으로 판단된다.

\section{Conclusion}

본 연구는 서울시에 거주하는 10 대-40대 여성들을 표본 집단으로 하여 2020년 9월 셋째 주부터 넷째 주까지 2주 동안 실시하였으며, 자기기입법으로 회신된 설문지 300 부 가운데 불성실한 응답을 제외 하고 유효한 자료인 271명만 최종 분석에 활용하였다.

본 실증분석을 통해 도출된 주요 결과는 다음과 같다.

첫째, 코로나 19 발생 이전·이후의 따른 화장에 대한 관심도 차이 를 살펴본 결과, 화장에 대한 관심도 전체와 하위 영역인 화장 필요 성, 제품 구매, 외모 만족에서 유의한 차이가 있었으며, 화장에 대한 필요성은 코로나19 발생 이후 $(\mathrm{M}=3.19)$ 가 이전 $(\mathrm{M}=3.50)$ 보다 더 낮 았으며, 유의한 차이가 있었다( $p\langle 0.001)$. 한편, 제품 구매는 코로나 19 발생 이후 $(\mathrm{M}=2.70)$ 가 이전 $(\mathrm{M}=2.86)$ 보다 더 낮았으며, 유의한 차 이가 있었고 $(p<0.05)$, 외모 만족은 코로나19 발생 이후 $(\mathrm{M}=2.71)$ 가 이전(M=3.08)보다 더 낮았으며, 유의한 차이가 있었다 $(p<0.001)$. 또 한, 화장에 대한 전반적인 관심도는 코로나 19 발생 이후 $(\mathrm{M}=2.79)$ 가 이전(M=2.99)보다 더 낮았으며, 유의한 차이가 있었다 $(p<0.001)$. 이 러한 결과는 코로나19 이후 메이크업 정도가 이전보다 낮아졌다는 $\mathrm{Kim} \& \mathrm{Li}$ (2020)의 연구결과와 맥락을 같이 하는 것으로 본 연구에 서도 코로나19 발생 이전에 비해 이후에 화장에 대한 전반적인 관심 도와 화장 필요성, 제품 구매, 외모 만족 등이 낮아졌음을 확인할 수 있었다. 또한 여성들의 외모관리 기대가치와 화장관심도가 정 $(+)$ 의 영향관계임을 확인한 Park \& Cho (2014)의 연구결과를 고려해 볼 때, 마스크 착용으로 인한 외모관리 기대가치 저하가 여성들의 화장 관심도를 낮춘 것으로 판단된다. 특히 화장관심도를 연령별로 살펴 본 결과, 20 대를 제외한 모든 연령대에서 통계적으로 유의하게 낮아 진 것을 알 수 있었는데 이는 20 대 여성들의 사회활동이 타 연령층에 비해 비교적 활발하고(Lee \& O, 2010) 외모에 대한 관심도가 높은 연령층 특성에 기인한 것으로 판단된다.

이렇듯 코로나19로 인해 사회적 거리두기와 언택트(Untact) 문화
가 형성됨에 따라 여성들의 외출이 최소화되고 비대면 사회활동이 증 가, 외출보다는 집에 있는 시간이 증가함에 따라 화장에 대한 인식과 필요성이 줄어든 것을 알 수 있었다. 마스크 착용이 의무화됨에 따라 화장품 구매가 줄어들게 되고 외모를 가꾸는 미용 목적의 화장이 줄 어들어 외모 만족도도 코로나 19 발생 이후에 더 낮아진 것으로 판단 되며, 코로나 19 발생은 여성들의 화장에 대한 관심도를 낮추었다.

둘째, 코로나 19 발생 이전·이후의 따른 화장품 사용실태 차이를 살펴본 결과, 립 메이크업이나 립스틱과 같은 입술 위주의 화장은 안 하거나 하더라도 코로나19 발생 이전에 비해 줄어든 것으로 나타났 다. 반면에 얼굴 전체를 대상으로 하는 화장인 파운데이션은 코로나 19 발생 이전·이후에는 큰 차이는 없었고 오히려 눈 화장이나 눈썹 화장과 피부 화장은 오히려 증가한 것으로 나타났다. 이러한 결과 는 재택근무, 사회적 거리두기 및 마스크 착용이 화장품 필요성을 감 소시키지만 아이(eye) 메이크업은 회복이 빠를 것이라는 Gerstell et al. (2020) 조사결과를 지지하는 것으로 마스크 착용으로 노출되지 않는 부분은 화장을 최소화하는 대신 노출되는 부위인 눈중심의 화 장에 중점을 두기 때문인 것으로 판단된다. 특히 마스크 착용이 접촉 되는 얼굴 부위에 피부 트러블을 유발(Kim \& Yu, 2020)할 수 있음 에 따라 피부 트러블을 최소화 하는 기능성 화장이 증가한 것으로 판 단된다.

또한 코로나19는 여성들의 화장품 구매방법과 비용에도 영향을 주는 것으로 나타났는데 코로나19 발생 이후에는 매장방문을 통한 구매보다는 온라인을 통한 비대면 구매가 늘어났으며, 화장비용도 고가 화장품은 지양하고 3 만원 미만의 화장품 사용량이 증가하는 것 을 알 수 있었다. 이러한 여성들의 화장관심도와 사용실태 차이가 주 는 시사점은 화장품 산업계에 의미가 있다. 즉 화장품 산업계는 포스 트 코로나를 대비하여 주로 입술 위주의 화장보다는 눈 중심의 화장 품 개발과 마케팅에 중점을 두어야 하며, 판매 방식도 기존의 방식을 탈피하여 백화점과 같은 오프라인 유통채널을 최소화하고 온라인 유 통을 강화해야 함을 시사한다. 본 연구를 통해 코로나 19 발생이 여 성들의 화장관심도와 화장품 사용실태에 많은 변화를 주었음을 확인 하였다.

코로나 19 의 장기화가 전망되고 있는 상황에서 여성들의 화장 관 심도와 화장품 사용실태는 더욱 변화될 것이며, 이러한 코로나19 환 경에 적합한 다양한 화장품들과 화장방법들이 유행하여 나타날 것으 로 판단된다.

\section{Author's contribution}

YMP designed all experimental investigations, HYK oversaw the project, and contributed to all aspects of analysis and experimental design.

\section{Author details}

Yun-Mi Park (Graduate student), Department of 
Humanimage, Konkuk University, 120 Neungdongro, Gwangjin-gu, Seoul 05029, Korea; Hwi-Yool Kim (Professor), Department of Veterinary Medicine, Konkuk University, 120 Neungdong-ro, Gwangjin-gu, Seoul, Korea.

\section{References}

Choi JS, Heo MR. Study on impact of heterosexual attachment types on interest in appearance and interest in make-up. Journal of Korean Traditional Costume, 22: 87-99, 2019.

De Cuyper C. Permanent makeup: indications and complications. Clinics in Dermatology, 26: 30-34, 2008.

Gerstell E, Marchessou S, Schmidt J, Spagnuolo E. How COVID-19 is changing the world of beauty. McKinsey \& Company Publishing, New Jersey, pp5-7, 2020.

Graham JA, Jouhar AJ. The effects of cosmetics on person perception. International Journal of Cosmetic Science, 3: 199-210, 1981.

Guo D, Sim T. Digital face makeup by example. 2009 IEEE Conference on Computer Vision and Pattern Recognition, Miami, FL, USA, pp73-79, 2009.

Kim HJ, Kwon HJ. A study on behavior patten of purchase and usage of cosmetic according to interest in appearance of adolescents. Asian Journal of Beauty and Cosmetology, 41: 353-359, 2014.

Kim MJ, Yu CM. The Effects of long-term mask wearing on aesthetic behavior: focusing on the COVID-19 pandemic. Journal of Korean Society of Beauty \& Art, 21:17-35, 2020.
Kim SY, Li SH. Correlation among wearing masks because of COVID-19, makeup satisfaction and goal-oriented attitude. Journal of Convergence for Information Technology, 10: 156-165, 2020.

Kim YE, Kim JD. A study on the use of color cosmetics according to women's appearance interest. Korean Society of Cosmetics and Cosmetology, 10: 289-305, 2020.

Korichi R, Pelle-de-Queral D, Gazano G, Auber A. Why women use makeup: implication of psychological. Journal of Cosmetic Science, 59: 127-137, 2008.

Lee HJ, O IY. The use of cosmetics in high school girls divided and grouped according to interest in make-up and make-up behavior. Journal of The Korean Society of Cosmetology, 16: 95-504, 2011.

$\mathrm{Na}$ YY, Song SY. The influence on make-up behavior and cosmetics consumption tendency to interest in appearance of female middle school students. The Korean Society of Science \& Art, 18: 221-233, 2014.

Park EH, Cho HJ. The influence of expected values for appearance management on interest in make-up and cosmetics evaluation criteria. Journal of Fashion Business, 18: 22-36, 2014.

Tae DS. Effects of appearance interest and information searches on makeup use behavior in Chinese high school girls. Journal of Investigative Cosmetology, 12: 379-388, 2016.

Ryu JH, Kim YS. Influence of interest in appearance of upper elementary school student on makeup behavior and self-esteem. Asian Journal of Beauty and Cosmetology, 67: 17-25, 2020. 


\section{국문초록}

\section{코로나19(COVID-19) 발생 이전·이후의 여성 화장 관심도 및 화장품 사용실태 변화 분석}

박윤미 ${ }^{1 *}$, 김휘율 ${ }^{2}$

${ }^{1}$ 건국대학교 휴먼이미지학과, 서울, 한국

${ }^{2}$ 건국대학교 수의학과, 서울, 한국

목적: 본 연구는 국내 10대-40대 여성들을 대상으로 코로나19 발생이 여성들의 화장에 대한 관심도와 사용에 어떠한 변화를 주었 는지를 실증분석을 통해 규명하는데 그 목적이 있다. 방법: 서울시에 거주하는 10대-40대 여성들을 표본집단으로 하여 2020년 9 월 셋째 주부터 넷째 주까지 2 주 동안 설문조사를 실시하였으며, 회신된 설문지 300 부 가운데 불성실한 응답을 제외하고 유효한 자 료인 271명만 최종 분석에 활용하였다. 결과: 화장에 대한 전반적인 관심도는 코로나19 발생 이후 더 낮아진 것으로 나타났다. 이 는 코로나19 발생 이전에 비해 이후에 화장에 대한 전반적인 관심도와 화장 필요성, 제품 구매, 외모 만족 등이 낮아진 것으로 코로 나 19 가 여성들의 화장관심도에 영향을 주도 있음을 의미한다. 또한 립 메이크업이나 립스틱과 같은 입술 위주의 화장은 코로나 19 발생 이전에 비해 줄어든 것으로 나타나 여성들의 화장품 사용실태에도 영향을 주는 것으로 나타났다. 결론: 본 연구를 통해 코로나 19 발생이 여성들의 화장관심도와 화장품 사용실태에 많은 변화를 주었음을 확인하였다. 코로나 19 의 장기화가 전망되고 있는 상황 에서 여성들의 화장 관심도와 화장품 사용실태는 더욱 변화될 것이며, 이러한 코로나 19 환경에 적합한 다양한 화장품들과 화장방법 들이 유행하여 나타날 것으로 판단된다.

핵심어: 외모 만족도, 코로나 19 , 화장관심도, 화장품 사용실태, 화장

\section{참고문헌}

김민정, 유채목. 장기간 마스크 착용이 피부미용행동에 미치는 영향 연구. 한국인체미용예술학회지, $21: 17-35,2020$. 김수영, 리순화. 코로나 19 로 인한 마스크 착용과 메이크업만족도, 목표지향적 태도의 상관관계. 융합정보논문지, 10 : 156-165, 2020.

김예은, 김주덕. 여성의 외모관심도에 따른 색조화장품 사용실태에 관한 연구. 한국화장품미용학회지, 10: 289-305, 2020.

김희자, 권혜진. 청소년의 외모관심도에 따른 화장품 사용실태와 구매행태 연구. 대한피부미용학회지, $12: 353-359$, 2014.

나윤영, 송선영. 여중생의 외모관심도가 화장행동 및 화장품 소비성향에 미치는 영향: 광주지역을 중심으로. 한국과학예술 융합학회지, 18: 221-233, 2014.

박은희, 조현주. 외모관리 기대가치가 화장관심도와 화장품 선택기준에 미치는 영향. 패션비즈니스, 18: 22-36, 2014. 유진희, 김영삼. 초등학교 고학년의 외모관심도가 화장행동과 자아존중감에 미치는 영향. 아시안뷰티화장품학술지, $18:$ $17-25,2020$.

이혜정, 오인영. 화장관심도와 정보탐색이 여고생의 화장행동에 미치는 영향. 한국인체미용예술학회지, $12: 65-84$, 2011.

최정순, 허미라. 여대생의 이성 관계 애착이 외모관심도와 화장관심도에 미치는 영향. 한복문화, 22: 87-99, 2019. 태동숙. 중국 여고생들의 외모관심도와 정보탐색이 화장행동에 미치는 영향. 대한미용학회지, 12: 379-388, 2016. 


\section{中文摘要}

\section{COVID-19爆发前后女性的化妆兴趣和使用情况变化的研究}

朴潤美 ${ }^{1 *}$, 金輝律 $^{2}$

建国大学动物医学系, 首尔, 韩国

2建国大学人文系，首尔，韩国

目的: 通过实证分析来调查Corona 19的爆发对10-40岁女性的化妆兴趣和使用情况的改变。方法: 从2020年9月 的第三周到第四周, 对居住在首尔的十几岁至40岁的女性进行了调查, 并使用SPSS 26.0程序对收集到的数据进 行了统计处理。结果: 发现在Corona 19爆发后, 人们对化妆品的总体兴趣降低了。这意味着, 与Corona 19爆 发前相比, 在爆发Corona 19之后, 人们对化妆品, 化妆品的需求, 产品购买和外观满意度的总体兴趣有所下 降。此外, 唇部彩妆（如唇妆和口红）与Corona 19爆发前相比似乎有所减少，这被发现会影响女性的化妆品使 用状态。结论: 已经表明, 强制使用口罩减少了女性的化妆品购买量, 并且减少了出于美容目的的化妆。另外, 发现除了戴着口罩时未暴露的部分（嘴唇）上的化妆最小化以外，对戴着口罩时暴露的部分（眼睛或面部）上 的化妆更感兴趣。

关键词: 外观兴趣, Corona 19，化妆品兴趣，化妆品使用情况，化妆 